\title{
Winter mortality and cold stress in Yekaterinburg, Russia: interview survey
}

\author{
G C Donaldson, V E Tchernjavskii, S P Ermakov, K Bucher, W R Keatinge
}

Department of

Physiology, Basic

Medical Sciences,

Queen Mary and

Westfield College,

University of

London, London

E1 4NS

G C Donaldson,

senior research

associate

W R Keatinge,

emeritus professor of

physiology

Russian Ministry of

Health,

11 Dobrolubova

Street, Moscow

127254, Russia

V E Tchernjavskii,

deputy director, public

health institute

S P Ermakov,

principal researcher

Dezemat

Biosynoptik der

Zentralen Medizin-

Meteorologischen

Forschungsstelle

des Deutschen

Wetterdienstes,

Stefan Maier

Strasse 4, 7800

Freiburg 1,

Germany

K Bucher,

head

Correspondence to:

Professor Keatinge

w.r.keatinge@

qmw.ac.uk

BMJ 1998;316:514-8

\begin{abstract}
Objectives: To evaluate how mortality and protective measures against exposure to cold change as temperatures fall between October and March in a region of Russia with a mean winter temperature below $-6{ }^{\circ} \mathrm{C}$.

Design: Interview to assess factors associated with cold stress both indoors and outdoors, to measure temperatures in living room, and to survey unheated rooms.
\end{abstract}

Setting: Sverdlovsk Oblast (district), Yekaterinburg, Russia.

Subjects: Residents aged 50-59 and 65-74 living within approximately $140 \mathrm{~km}$ of Yekaterinburg in Sverdlovsk Oblast. Survey of sample of 1000 residents equally distributed by sex and age groups.

Main outcome measures: Regression analysis was used to relate data on indoor heating and temperatures, the amount of clothing worn, the amount of physical activity, and shivering while outside, to outdoor temperature; results were compared with mortality patterns for ischaemic heart disease, cerebrovascular disease, respiratory disease, and mortality from all causes.

Results: As mean daily temperatures fell to $0^{\circ} \mathrm{C}$ the amount of clothing worn outdoors increased, physical activity while outdoors became more continuous, and only $11(6.6 \%)$ of the 167 people surveyed who went outdoors at temperatures above $0^{\circ} \mathrm{C}$ reported shivering. The mean temperature in living rooms in the evening remained above $21.9^{\circ} \mathrm{C}$. Mortality from ischaemic heart disease, cerebrovascular disease, respiratory disease, and all causes did not change. As the temperature fell below $0^{\circ} \mathrm{C}$ the number of items of clothing worn plateaued at 16.0 and the number of layers at 3.7. With regression analysis, shivering outdoors was found to increase progressively to $34.6 \%(\mathrm{P}<0.001)$ of excursions at $-25^{\circ} \mathrm{C}$, and mortality (after declining slightly) rose progressively (all cause mortality rose by $1.15 \%$ for each $1^{\circ} \mathrm{C}$ drop in temperature from $0^{\circ} \mathrm{C}$ to $-29.6^{\circ} \mathrm{C}, 95 \%$ confidence interval $0.97 \%$ to $1.32 \%$ ). $94.2 \%$ of bedrooms were directly heated, and evening temperatures in the living room averaged $19.8^{\circ} \mathrm{C}$ even when outside temperatures reached $-25^{\circ} \mathrm{C}$.

Conclusions: Outdoor cold stress and mortality in Yekaterinburg increased only when the mean daily temperature dropped below $0^{\circ} \mathrm{C}$. At temperatures down to $0^{\circ} \mathrm{C}$ cold stress and excess mortality were prevented by increasing the number of items of clothing worn and the amount of physical activity outdoors in combination with maintaining warmth in houses.

\section{Introduction}

In cold and temperate regions mortality is minimal at about $18^{\circ} \mathrm{C}$ but rises as temperatures fall. ${ }^{1-3}$ Much of the increase in mortality seems to be associated with cold stress (personal exposure to cold); time series analyses have shown that mortality increases within 24 hours of a fall in temperature. ${ }^{4}$ Deaths from thrombosis, which account for most of the excess mortality associated with cold, are probably caused by haemoconcentration resulting from cold stress (general exposure to cold $)^{56}$ and an increase in plasma fibrinogen concentrations as a result of an acute response to respiratory infections..$^{78}$ The increase in mortality that occurs with each fall of $1^{\circ} \mathrm{C}$ in outdoor temperature is smaller in areas of Europe where houses are warmer and more clothing is worn outdoors at a given outdoor temperature. ${ }^{9}$ However, it is unclear whether protection against cooling of the body surface alone can entirely prevent higher mortality in winter. This protection would not be effective if, for example, local cooling of the respiratory tract caused by breathing cold air was an important factor in the deaths.

This paper reports patterns of winter mortality and various strategies for protection against cold in the Yekaterinburg region of Russia, 850 miles east and slightly north of Moscow. It is a densely populated region, where many people spend substantial time outdoors. The mean winter temperature is $-6.8^{\circ} \mathrm{C}$, lower than that in any part of western Europe (fig 1). Our objective was to evaluate whether the type and amount of outdoor clothing worn and the amount of physical activity prevented excess mortality when winter temperatures were similar to those found in western European regions with milder winters.

\section{Subjects and methods}

\section{Subjects and survey of lifestyle}

Subjects were selected for interview by a two stage process. ${ }^{11}$ Primary sampling areas were designated from census data and selected to be representative of population density and composition of social groups. Each interviewer was allocated a sampling area each day. To

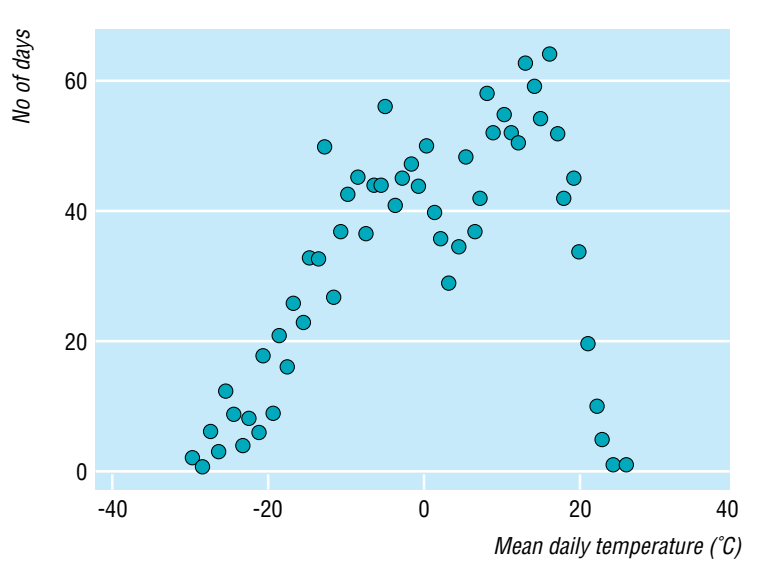

Fig 1 Numbers of days at each mean daily temperature from 1990 to 1994 inclusive in Yekaterinburg, Russia 
prevent clustering, interviews were separated by at least four addresses and no more than two interviews were conducted on each street; apartment blocks were considered to be streets. Samples of responses were checked by telephone or by post for quality control. These procedures were similar to those used in the Eurowinter survey in western Europe. ${ }^{9}$ The survey was conducted by a Russian-Finnish company associated with Gallup and with advice from Colin McDonald (McDonald Research, Camberley). Briefing of interviewers and the initial interviews in Yekaterinburg were monitored by WRK and by the survey consultant.

Interviews were conducted from the beginning of October 1995 through to the end of February 1996. Interviews occurred on all days of the week. Interviews took place after 1700 in the main living room of the house or apartment. Temperatures were measured to $1^{\circ} \mathrm{C}$ with Thermax temperature strips (Thermographic Measurements, Burton) which were placed on furniture $0.5 \mathrm{~m}$ to $1.2 \mathrm{~m}$ above the floor. Interviewers then completed questionnaires. Interviewees were asked about the duration of heating in the bedroom and living room, the duration and number of outdoor excursions, the type of clothing worn outdoors, and physical activity outdoors during the previous 24 hours; interviews were conducted in Russian.

\section{Mortality and temperature}

Daily reports of deaths during 1990-4 were obtained for Yekaterinburg and the regions and towns of the Sverdlovsk Oblast (district) which are within about 140 $\mathrm{km}$ of Yekaterinburg; the data were reported for those aged 50-59 and 65-74 and for men and women. Census data were used to determine numbers of each sex and age group. There were 192000 men and 258000 women aged 50-59 and 77000 men and 167000 women aged 65-74. The mean daily temperature was calculated using measurements taken every three hours in Yekaterinburg.

\section{Regression analysis}

Regression coefficients for the number of deaths each day in relation to the mean daily temperature were estimated for temperatures between $0^{\circ} \mathrm{C}$ and $18^{\circ} \mathrm{C}$ and for temperatures between $0^{\circ} \mathrm{C}$ and $-25^{\circ} \mathrm{C}$; generalised linear modelling with identity link function was used and a Poisson distribution was assumed. ${ }^{10}$ Regression coefficients were expressed as a percentage of the estimated mortality at baseline, which was taken as $18^{\circ} \mathrm{C}$. Deaths were lagged on temperature by 2 days for ischaemic heart disease, by 5 days for cerebrovascular disease, by 12 days for respiratory disease, by 3 days for all cause mortality; these are the delays which give maximal effects. ${ }^{4}$ Deaths from influenza averaged over the 10 days before to the 10 days after each mortality were included in the regression model as a second explanatory variable to account for the effects of influenza; these effects were small as only nine deaths from influenza were recorded. For graphs, mortality data per million population were averaged for each temperature interval of $1^{\circ} \mathrm{C}$.

Separate regressions on the mean daily temperatures both above and below $0^{\circ} \mathrm{C}$ were made by ordinary least squares regression for the temperature in the living room. Generalised linear modelling was used for Poisson distributed data, and logit regression was used for binary data. ${ }^{10}$
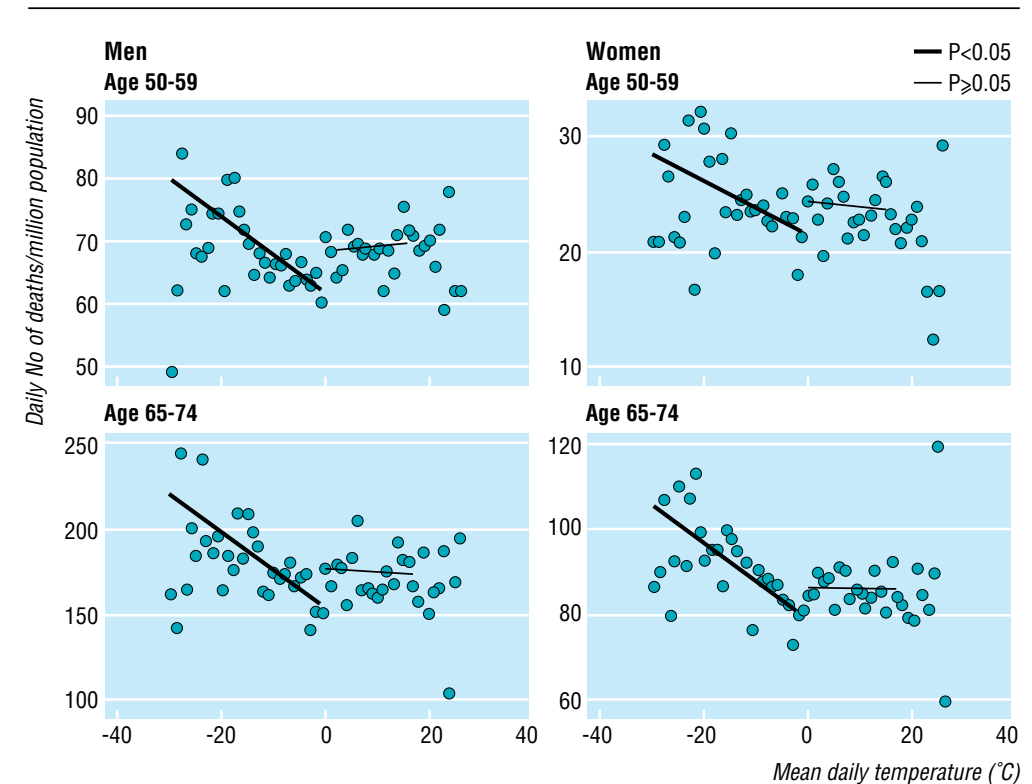

Fig 2 Daily numbers of deaths per million population in each sex and age group by mean daily temperature
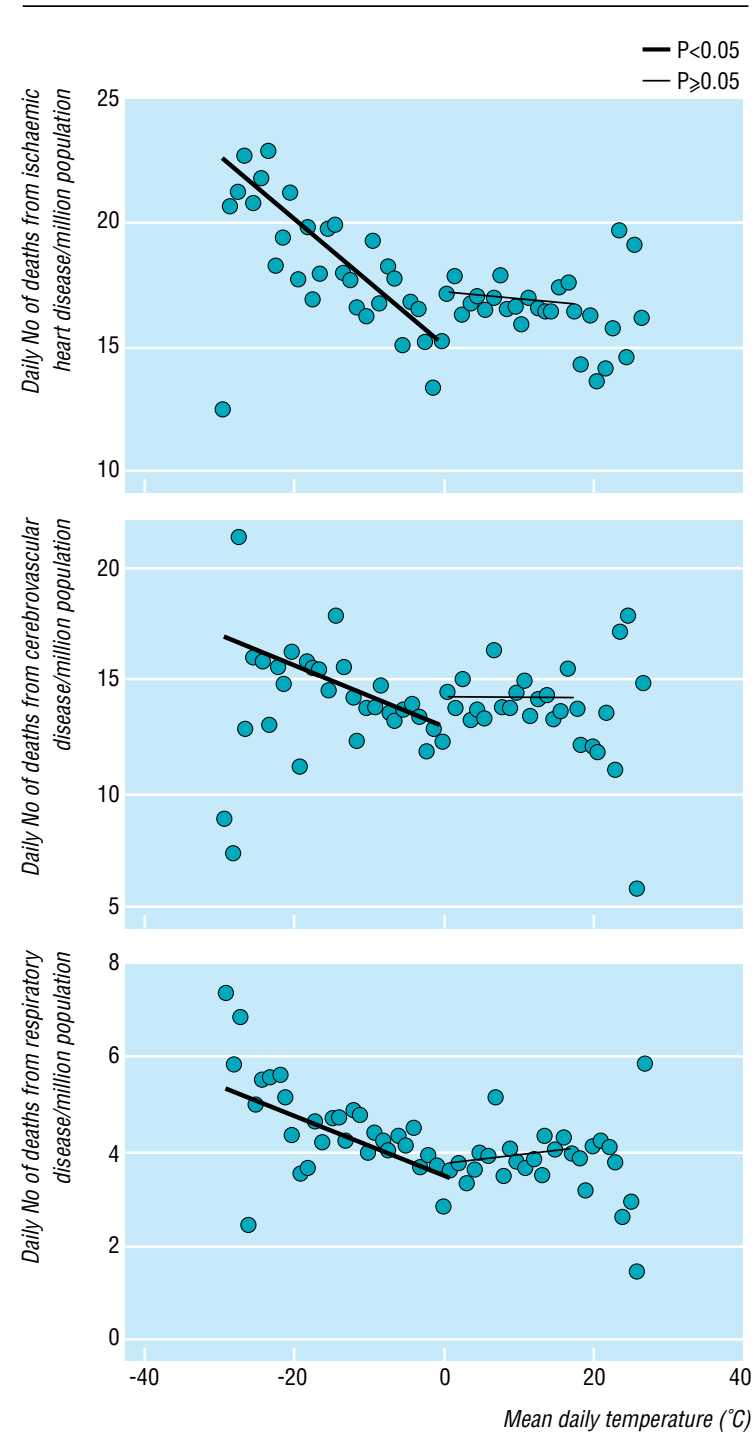

Fig 3 Daily numbers of deaths from ischaemic heart disease, cerebrovascular disease, and respiratory disease per million population by mean daily temperature 
The number of layers of clothing worn was calculated as the total area of all items of clothing and expressed as a fraction of body surface area; this was calculated from the list of garments worn and from the surface area of specific parts of the body of men and women. ${ }^{12}$ There was no theoretical case for using a particular model to analyse the number of pieces of clothing worn and the total area covered by the clothing. Since both seemed to fall in a linear fashion as the mean daily temperature fell to $0^{\circ} \mathrm{C}$, then fell more slowly and plateaued below $-8^{\circ} \mathrm{C}$ these factors were tested by separate linear regressions for temperatures below $-8^{\circ} \mathrm{C}$, for temperatures from $-8^{\circ} \mathrm{C}$ to $0^{\circ} \mathrm{C}$, and for temperatures above $0^{\circ} \mathrm{C}$. The Student's $t$ test was used to compare mortality at temperatures from $0^{\circ} \mathrm{C}$ to $-5^{\circ} \mathrm{C}$ with mortality from $0^{\circ} \mathrm{C}$ to $5^{\circ} \mathrm{C}$. Values are given as means with $95 \%$ confidence intervals except when otherwise stated.

\section{Results}

A total of 1000 people in the region were interviewed; respondents were equally divided between men and women and between the ages of 50-59 and 65-74.

Mean daily temperatures from 1990 to 1994 inclusive varied from $26.5^{\circ} \mathrm{C}$ to $-29.6^{\circ} \mathrm{C}$ during the time
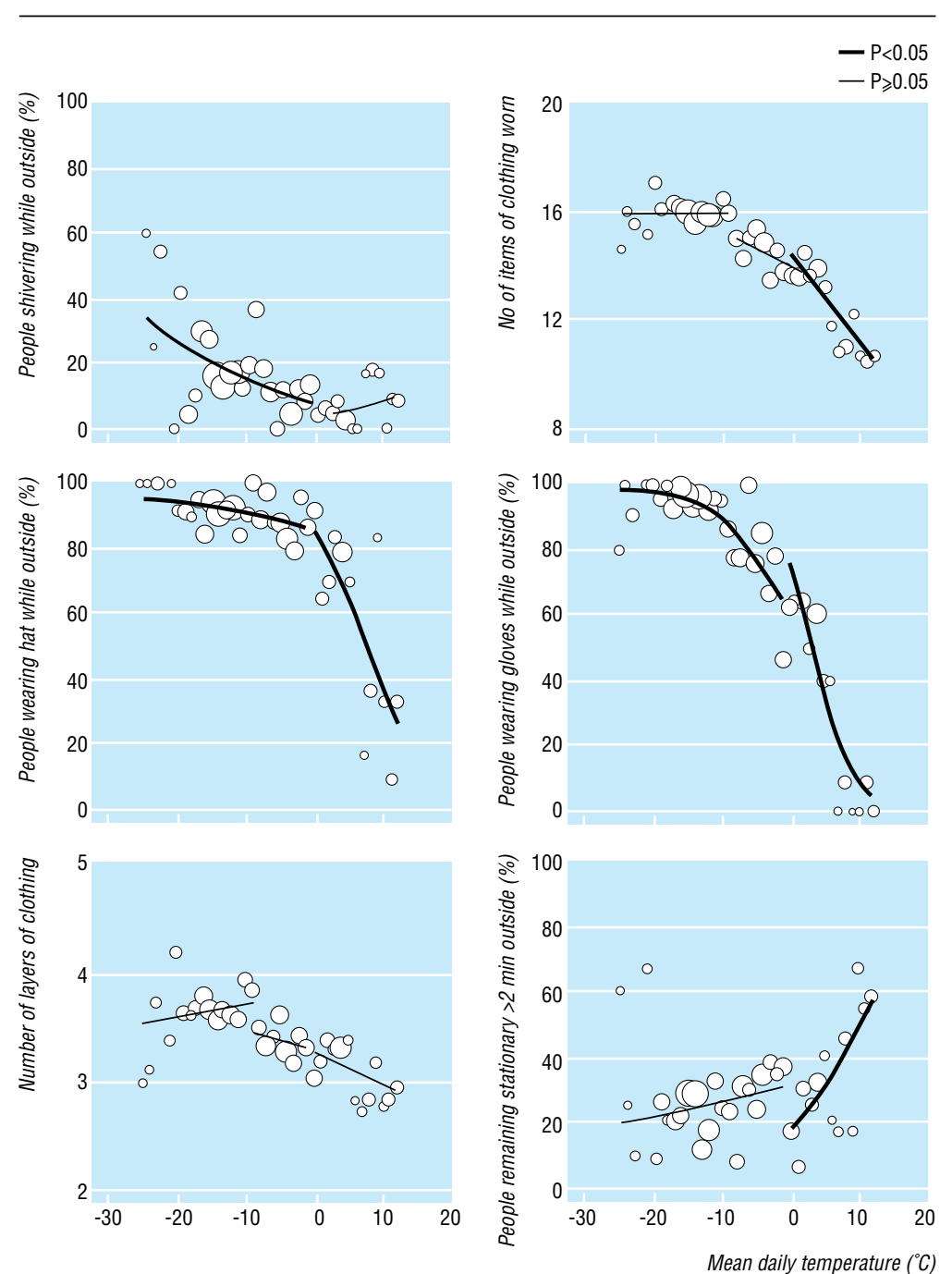

Fig 4 Numbers of items and types of clothing worn, body area covered by clothing, percentages of those who remained stationary when outdoors, and percentages of those who reported shivering while outdoors by mean daily temperature that the mortality data were collected. Temperatures varied between $12.5^{\circ} \mathrm{C}$ and $-25^{\circ} \mathrm{C}$ during the survey. The mean winter temperature (between October and March 1990 to 1994 inclusive) was $-6.8^{\circ} \mathrm{C}$; this was $4^{\circ} \mathrm{C}$ colder than the coldest region surveyed in western Europe in the Eurowinter survey $\left(-2.8^{\circ} \mathrm{C}\right.$ in northern Finland $) .^{9}$

\section{Mortality}

Mortality from all causes did not change as the mean daily temperature fell to $0^{\circ} \mathrm{C}$. At slightly below $0^{\circ} \mathrm{C}$, however, mortality fell by $6.1 \%(\mathrm{P}=0.011)$ as it does in Britain. ${ }^{4}$ This may be due to the bactericidal effects of freezing. None the less, mortality then increased progressively by $1.15 \%$ (0.97\% to $1.32 \%)$ for each drop in temperature by $1^{\circ} \mathrm{C}$ as temperatures fell from $0^{\circ} \mathrm{C}$ to $-29.6^{\circ} \mathrm{C}(\mathrm{P}<0.001)$. There was no increase in mortality related to increases in temperatures above $18^{\circ} \mathrm{C}^{1 .}{ }^{9}$ These patterns were similar for men and women and for those aged 50 to 59 and 65 to 74 (fig 2). The relations in each temperature range were broadly linear (fig 2). Absolute mortality in men was more than double that in women; absolute mortality among those aged 65 to 74 was more than double that among those aged 50 to 59 .

The relation between mortality and temperature was not different for ischaemic heart disease, cerebrovascular disease, respiratory disease, or death from all causes (fig 3). Information on the specific cause of death was extracted from the mortality data; there were an average of 11.5 deaths related to ischaemic heart disease each day, 9.4 related to cerebrovascular disease, 2.7 related to respiratory disease, and a total of 46.6 for all causes of death. When the data were plotted for each year there was no systematic change in the relation of mortality to temperature with time although absolute mortality rose with time.

\section{Behaviour outdoors}

Most people reported going outside every day for at least 10 minutes $(83 \%$ to $87 \%$ of the 1000 people surveyed). The total time spent outside each day averaged 39 minutes (37 to 41 minutes); neither the amount of time spent outside nor the percentage of people who had gone outside in the last 24 hours was significantly related to the mean daily temperature when temperatures were either above or below $0^{\circ} \mathrm{C}$. Many people travelled to work by bus or train, waited outdoors for transport, and walked to transport (WRK, personal observation).

As temperatures outdoors fell to $0^{\circ} \mathrm{C}$ the people who went outdoors seldom shivered; only 11 of the 167 people who were surveyed $(6.6 \% ; 2.6 \%$ to $9.6 \%)$ reported shivering while out that day, and the percentage of those who did shiver did not change with the temperature (fig 4). A probable explanation for this is that when people went outdoors they reported wearing progressively more clothing as the temperature fell to $0^{\circ} \mathrm{C}$ and they also reported spending less time stationary $(\mathrm{P}<0.001)$. When linear regression was used for temperatures below $0^{\circ} \mathrm{C}$, the percentage of those who shivered while outside increased to $34.6 \%$ at $-25.0^{\circ} \mathrm{C}(\mathrm{P}<0.001)$, while the number of items of clothing increased little and stabilised at 16 items when temperatures fell below $-8^{\circ} \mathrm{C}$ (fig 4 ). In temperatures below $0^{\circ} \mathrm{C}$ the number of people who kept still while outside (mean 26\%; $22 \%$ to $29 \%$ ) changed little; there was no significant decline as temperatures fell from 
$0^{\circ} \mathrm{C}$ to $-25^{\circ} \mathrm{C}$. Through the whole range of temperatures the wearing of hats and gloves followed similar patterns to the total number of items of clothing worn (fig 4). Estimates of the total area of clothing (fig 4) were too scattered to reach significance but suggested a rise in the area covered as temperatures fell to $0^{\circ} \mathrm{C}$ and a plateau at temperatures below $-8^{\circ} \mathrm{C}$ at 3.67 layers or $367 \%(360 \%$ to $374 \%)$ of body surface area (fig 4). Conversations in Yekaterinburg by WRK suggested that all available outdoor clothing was then being worn.

\section{Indoor temperatures}

The mean temperature in the living room in the evening measured during interviews was high throughout the entire range of outdoor temperatures studied. It declined only a little from $23.1^{\circ} \mathrm{C}\left(21.4^{\circ} \mathrm{C}\right.$ to $24.8^{\circ} \mathrm{C}$ ) at outdoor temperatures of $12.7^{\circ} \mathrm{C}$, to $21.9^{\circ} \mathrm{C}$ $\left(20.3^{\circ} \mathrm{C}\right.$ to $\left.23.5^{\circ} \mathrm{C}\right)$ at outdoor temperatures of $0^{\circ} \mathrm{C}$, and to $19.8^{\circ} \mathrm{C}\left(18.8^{\circ} \mathrm{C}\right.$ to $\left.20.9^{\circ} \mathrm{C}\right)$ at outdoor temperatures of $-25.0^{\circ} \mathrm{C}$ (fig 5). The temperature of the living room in the evening was $22.6^{\circ} \mathrm{C}\left(20.9^{\circ} \mathrm{C}\right.$ to $\left.24.2^{\circ} \mathrm{C}\right)$ when outdoor temperatures were $7^{\circ} \mathrm{C}$, at which temperature
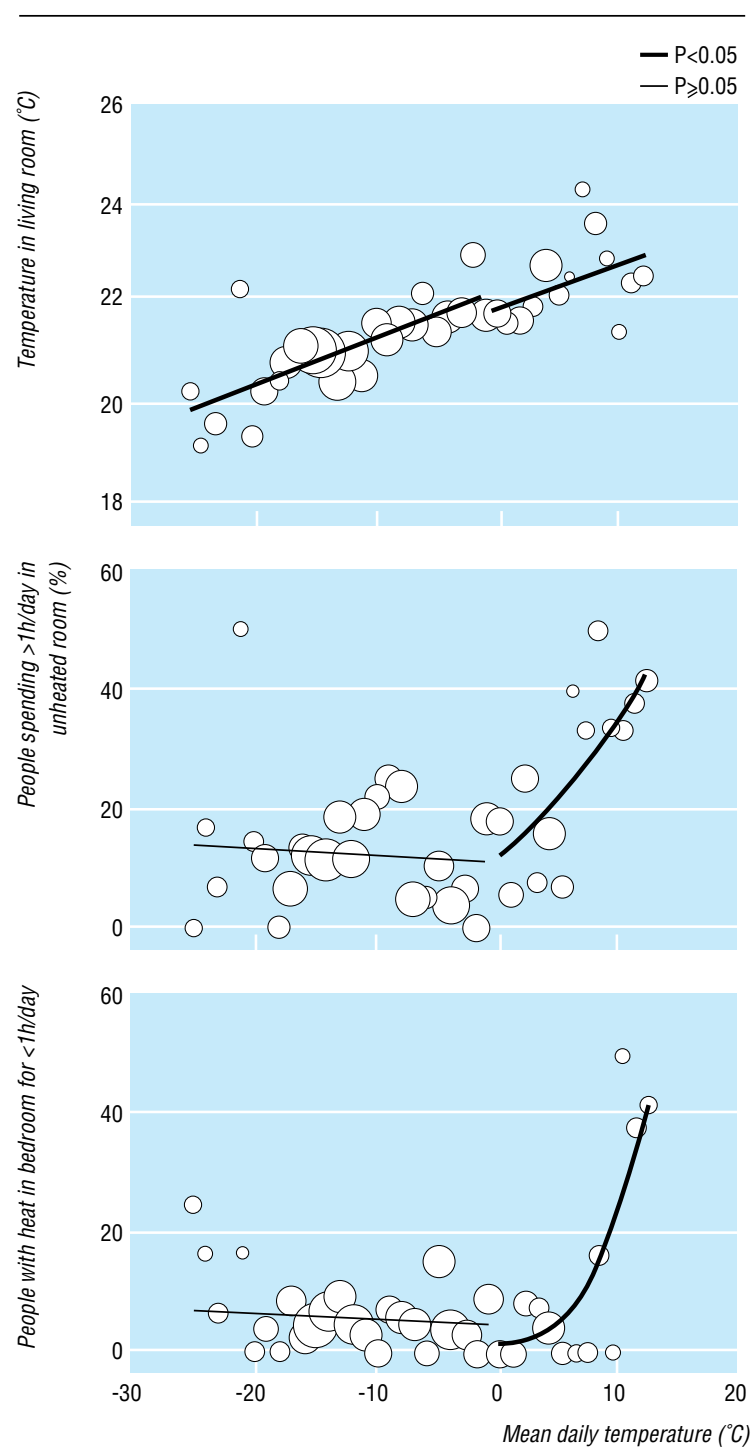

Fig 5 Temperatures $\left({ }^{\circ} \mathrm{C}\right)$ in living room at time of interview, percentages of subjects spending $>1 \mathrm{~h} /$ day in an unheated room, and percentages of subjects with unheated bedrooms (heated $<1 \mathrm{~h} /$ day) by mean daily temperature the Eurowinter survey data was standardised. ${ }^{9}$ Daytime visits to unheated parts of the house or apartment and the numbers of people sleeping in unheated bedrooms declined as outdoor temperatures fell from $12.7^{\circ} \mathrm{C}$ to $0^{\circ} \mathrm{C}$ (fig 5); at temperatures below $0^{\circ} \mathrm{C}$ they stabilised with $12 \%$ visiting unheated parts of the house by day and 5.8\% sleeping in unheated bedrooms (fig 5). Personal observation by WRK showed that rooms which were not heated in cold weather were often small and opened directly on to heated rooms and thus received indirect heating.

\section{Discussion}

Lack of cold stress at temperatures above $0^{\circ} \mathrm{C}$

This study found that as outdoor temperatures fell to $0^{\circ} \mathrm{C}$ in Yekaterinburg there was no increase in mortality from ischaemic heart disease, cerebrovascular disease, respiratory disease, or all causes. High temperatures indoors in combination with an increase in the number of layers of clothing worn and the amount of physical activity when outdoors generally prevented cold stress. Both the fall in temperature to $0^{\circ} \mathrm{C}$ and the associated increase in physical activity when outdoors increase local cooling of the respiratory tract, but without general chilling and cooling did not lead to any detectable increase in mortality.

The mean temperature in the living room in the evening declined slightly as outdoor temperatures fell. When outdoor temperatures reached $0^{\circ} \mathrm{C}$ living room temperatures were $21.9^{\circ} \mathrm{C}$; this is higher than temperatures found in living rooms in western Europe when outdoor temperatures reached $7^{\circ} \mathrm{C} .{ }^{9}$ The indoor temperatures found in this study are expected to have permitted full thermal comfort indoors. Home heating in Yekaterinburg generally could not be controlled by the occupants; the increase in the amount of time spent in unheated parts of the house during the day and in unheated bedrooms at night when the outdoor temperature was above $0^{\circ} \mathrm{C}$ suggests that heated rooms were at or above optimally comfortable temperatures and people chose to spend time in unheated rooms.

Cold stress and mortality at temperatures below $0^{\circ} \mathrm{C}$ Several factors may have contributed to the increase in mortality that occurred when outdoor temperatures fell from $0^{\circ} \mathrm{C}$ to $-29.6^{\circ} \mathrm{C}$. An increase in outdoor cold stress was indicated by an increase in shivering. The amount of outdoor clothing that was worn plateaued when temperatures were slightly below $0^{\circ} \mathrm{C}$; there were no further increases in the amount of clothing worn when temperatures fell further, apparently because people did not have additional items of outdoor clothing to wear. Cold stress is unlikely to have occurred indoors even when outdoor temperatures were below $0^{\circ} \mathrm{C}$ since mean temperatures in living rooms were $19.8^{\circ} \mathrm{C}$ when outdoor temperatures reached $-25^{\circ} \mathrm{C}$. At these temperatures unheated rooms generally received indirect heating and were not occupied for long. However, when temperatures fell from $0^{\circ} \mathrm{C}$ to $-29.6^{\circ} \mathrm{C}$ the small fall in indoor temperature from $23.1^{\circ} \mathrm{C}$ to $19.8^{\circ} \mathrm{C}$, occasional visits to unheated rooms, or cooling of the respiratory tract by breathing cold air when outdoors may have contributed to the increase in mortality. The results do not exclude the possibility that genetic or lifetime adaptations to cold by the 
mortality. VET and SPE were responsible with staff in Yekaterinburg for assembly and initial analysis of mortality data, they participated in consultations on the design of the study, interpretation of results, and editing the paper. $\mathrm{KB}$ provided the climatic data and contributed to editing the paper. WRK initiated the study proposals, designed the study, commissioned the field survey through the field consultant, visited Yekaterinburg with the consultant at the start of the survey, drafted the paper, and is guarantor for the study.

Funding: The study was funded by the PECO scheme of the European Union for cooperation in science and technology with central and eastern European countries and with newly independent states of the former Soviet Union.

Conflict of interest: None. clothing and engaging in physical activity outdoors, and by adequately heating houses

population of Yekaterinburg have lowered mortality in winter to rates below what they would otherwise be.

\section{Relation between cold stress and mortality}

The general cold stress and mortality related to cold seen at temperatures below $0^{\circ} \mathrm{C}$ in Yekaterinburg, and their absence at temperatures above $0^{\circ} \mathrm{C}$, can be most easily explained by a causal relation between mortality and cold stress. These results reinforce those of our earlier study, which showed an association between cold stress and mortality among different populations in western Europe ${ }^{9}$; they also support the findings of a time series analysis which showed close temporal associations between cold weather and cause-specific mortalities in England. ${ }^{4}$ The results of this study suggest that most of the increase in mortality associated with cold weather in western Europe-which occurs mainly at temperatures above $0^{\circ} \mathrm{C}$-could be prevented by a combination of simple protective measures against outdoor cold and ensuring that houses are warm.

We thank Dr Ruslan Halfin, head of the Health Department Administration, Sverdlovsk Oblast, and Dr Tamara Gribanova, director of the Regional Medical Computer Centre, Sverdlovsk Oblast, for the data on mortality.

Contributors: GCD contributed to designing the study, writing the paper, and computing the survey data and its relation to
Bull GM, Morton J. Environment, temperature and death rates. Age Ageing 1978;7:210-24.

2 Frost DB, Auliciems A, de Freitas C. Myocardial infarct death and temperature in Auckland, New Zealand. Int J Biometeorol 1992;36:14-7.

Heunis JC, Olivier J, Bourne DE. Short-term relationships between winter temperatures and cardiac disease mortality in Cape Town. $S$ Afr Med J 1995:85:1016-9.

4 Donaldson GC, Keatinge WR. Early increases in ischaemic heart disease mortality dissociated from, and later changes associated with, respiratory mortality, after cold weather in south-east England.J Epidemiol Community Health 1997;51:643-8.

5 Keatinge WR, Coleshaw SRK, Cotter F, Mattock M, Murphy M, Chelliah $\mathrm{R}$. Increases in platelet and red cell counts, blood viscosity, and arterial pressure during mild surface cooling: factors in mortality from coronary and cerebral thrombosis in winter. BMJ 1984;289:1405-8.

6 Neild PJ, Syndercombe-Court D, Keatinge WR, Donaldson GC, Mattock $\mathrm{M}$, Caunce M. Cold-induced increases in erythrocyte count, plasma cholesterol and plasma fibrinogen of elderly people without a comparable rise in protein C or factor X. Clin Sci 1994;86:43-8.

7 Woodhouse PR, Khaw K-T, Plummer M, Foley A, Meade TW. Seasonal variations of plasma fibrinogen and factor VII activity in the elderly: winter infections and death from cardiovascular disease. Lancet 1994;343:435-9. possible trigger for acute myocardial infarction? Int J Epidemio 1978:7:231-9.

9 Eurowinter Group. Cold exposure and winter mortality from ischaemic heart disease, cerebrovascular disease, respiratory disease, and all causes in warm and cold regions of Europe. Lancet 1997;349:1341-6.

10 Lovett AA, Bentham CG, Flowerdew R. Analysing geographical variations in mortality using Poisson regression: the example of ischaemic heart disease in England and Wales 1969-1973. Soc Sci Med 1986;23:935-43.

11 Gray PG, Corlett T. Sampling for the social survey. J R Stat Soc Ser A 1950;113:150-99.

12 Hayward MG, Keatinge WR. Roles of subcutaneous fat and thermoregulatory reflexes in determining ability to stabilize body temperature in water.J Physiol (Lond) 1981; 320: 229-251.
8 Bainton D, Jones GR, Hole D. Influenza and ischaemic heart disease-a

(Accepted 31 October 1997)
Department of

Medical

Epidemiology,

Karolinska Institute,

PO Box 281, S-171

77 , Stockholm,

Sweden

Anders Ekbom,

associate professor

Göran Lundegårdh, physician

Olof Nyrén,

associate professor

continued over

BMJ 1998;316:518-9
Smoking increases the risk of peptic ulcer disease and also adversely affects its course. ${ }^{1}$ Both pharmacological and surgical treatments will lead to a relief from the symptoms of the disease. ${ }^{2}$ We analysed to what extent such potential relief would affect the subsequent risk of lung cancer in patients who had had a vagotomy for peptic ulcer disease, compared with patients with the disease who were treated without surgery.

\section{Subject, methods, and results}

Through the inpatient registry, which in 1983 covered $85 \%$ of the Swedish population, we identified 67812 patients admitted to hospital between 1965 and 1983 for peptic ulcer disease but who did not have a vagotomy. Through the same registry we also identified 7198 patients who had a vagotomy between 1971 and 1979. Through linkage with the Swedish death and emigration registry as well as the Swedish cancer registry, all new cases of lung cancer in the two cohorts were identified until the end of 1989. Expected numbers of new cases were estimated from age specific and period specific population rates.

After we excluded the first year after vagotomy, the ratio of observed to expected cases up to the end of the follow up was $2.20(95 \%$ confidence interval $=1.82$ to 2.63 ), with an increase in the ratio from 1.86 (one to five years after operation) to 2.52 (10 years or more after operation). Among the patients with peptic ulcer disease who had not had a vagotomy the ratio of 